\title{
Kesehatan dan Kualitas Kehidupan Kerja terhadap Kinerja Perawat di Rumah Sakit Umum Tangerang
}

\author{
Health and Quality of Work Life on The Performance of Nurses at \\ Tangerang General Hospital
}

\author{
Hafizurrachman* Laksono Trisnantoro** Adang Bachtiar*
}

*Departemen Administrasi Kebijakan dan Kesehatan Fakultas Kesehatan Masyarakat Universitas Indonesia, **Ilmu Kesehatan Masyarakat Fakultas Kedokteran Universitas Gadjah Mada

\begin{abstract}
Abstrak
Penelitian ini bertujuan melihat pengaruh dan besaran berbagai variabel kesehatan dan kualitas kehidupan kerja terhadap kinerja perawat di Rumah Sakit Umum (RSU) Tangerang. Variabel kesehatan tersebut meliputi sejarah kesehatan keluarga, lingkungan kehidupan, perilaku gaya hidup, dan status kesehatan perawat. Desain penelitian yang digunakan pada penelitian ini adalah desain potong lintang. Data dianalisis dengan pendekatan Structural Equation Model (SEM) menggunakan software Smart-PLS. Populasi yang diamati adalah perawat yang bertugas di semua pelayanan RSU Tangerang dengan 250 perawat terpilih sebagai sampel yang dilakukan secara multistage random sampling. Hasil analisis menunjukkan bahwa kinerja perawat di RSU Tangerang dipengaruhi oleh semua variabel, yang berarti model teoritis yang diusulkan pada penelitian ini dapat digunakan sebagai variabel prediktor. Pada model, variabel kualitas kehidupan kerja perawat merupakan variabel prediktor terbesar yang memengaruhi kinerja perawat. Dengan demikian, variabel kinerja perawat dipengaruhi oleh banyak variabel dengan pengaruh yang relatif kecil $(6,16 \%)$. Intervensi terhadap semua variabel yang ditawarkan pada penelitian ini akan memberikan hasil yang kecil terhadap kinerja perawat sehingga memerlukan intervensi tambahan pada variabel lain.

Kata kunci: Kinerja perawat, kualitas kehidupan kerja, kesehatan
\end{abstract}

\begin{abstract}
This study aims to see the effect and magnitude of health variables and variable of the quality of work life on the performance of nurses working in Tangerang General Hospital. Health variables include family medical history, living environment, lifestyle behaviors, and health status. Crosssectional method used in this study. Data were analyzed with the approach to Structural Equation Model (SEM) using software Smart-PLS. In this study nurses who serve in all services at Tangerang General Hospital was chosen as the unit of analysis with 250 nurses was selected as the samples and multistage random sampling were used. The results of the analysis
\end{abstract}

showed that the performance of nurses in Tangerang General Hospital was influenced by all the variables which means that the theoretical model proposed in this study can be used. The quality of work life of nurse was the greatest predictor variables in the model that affect the performance of nurses. Thus, this study concluded that the variable performance of nurses is affected by many variables with its influence was relatively small $(6,16 \%)$. Therefore all the variables offered in this study will intervene not large enough results to produce an excellent performance of the nurses at Tangerang General Hospital and required additional intervention efforts on other variables.

Key words: Nurses performance, quality of work life, health

\section{Pendahuluan}

Kerja prima pada suatu rumah sakit merupakan kebutuhan mutlak dalam membantu penyembuhan pasien. ${ }^{1}$ Pada proses perawatan di rumah sakit, pasien yang lebih cepat sembuh mengurangi biaya yang dikeluarkan pasien dan pemerintah secara tidak langsung akan mendapatkan manfaat. Subsidi kepada pasien yang selama bertahun-tahun terus meningkat, pada gilirannya dapat diturunkan. ${ }^{2}$ Daerah dengan rasio orang sakit yang tinggi akan memperlihatkan penurunan tingkat kompetitif dan produktivitas yang lebih tinggi daripada daerah dengan rasio orang sakit yang rendah. ${ }^{3}$ Dengan demikian, upaya untuk mempertahankan keadaan sehat pada suatu populasi menjadi sangat penting. Upaya tersebut menjadi bagian yang tidak terpisahkan dari peran para perawat rumah sakit untuk

Alamat Korespondensi: Hafizurrachman, Departemen Administrasi Kebijakan dan Kesehatan FKM Universitas Indonesia, Gd. F Lt. 1 Kampus Baru UI Depok 16424,Hp.0818120663,e-mail: hafizurrachman@gmail.com 
bekerja secara sungguh-sungguh dan tulus atau bekerja secara prima dalam mempercepat proses penyembuhan pasien. ${ }^{1}$

Untuk menghasilkan kinerja yang prima, seorang perawat rumah sakit harus mempunyai status kesehatan prima dengan dilandasi oleh faktor genetik yang dapat direpresentasikan oleh sejarah kesehatan keluarga.1,4 Keadaan ini dapat membentuk lingkungan kehidupan yang kondusif dan perilaku berkarakter. ${ }^{4,5}$ Selanjutnya, lingkungan kerja yang menyenangkan dan sehat dapat dibentuk oleh perilaku gaya kehidupan perawat yang seimbang pula sehingga dapat mempengaruhi status kesehatan dan kualitas kehidupan kerja perawat hingga akhirnya membentuk kinerja yang tinggi. 4,6 Keadaan status kesehatan seseorang tidak lepas dari keadaan sejarah kesehatan keluarganya seperti perkembangan diri menuju dewasa yang membentuk tingkat kesehatan dan berperan banyak dalam kemampuan bekerja. ${ }^{7}$ Kesehatan menjadi modal utama untuk bekerja sehingga pemeliharaan kesehatan perawat akan membuat mereka mempunyai ketahanan bekerja atau stamina cukup untuk bekerja yang dapat menjadi dasar kualitas hidup seorang perawat dalam bekerja. 6,8

Lingkungan kerja meliputi lingkungan fisik di tempat kerja, rumah, serta berbagai aturan-aturan kerja yang membentuk suasana dan semangat kerja perawat yang berimplikasi pada kinerja. ${ }^{9}$ Lebih jauh, lingkungan kerja bersama variabel lain seperti sejarah kesehatan, perilaku individu, dan manajemen kesehatan secara teoritis memberikan pengaruh kepada status kesehatan individu. 4,10 Keempat variabel ini secara sendiri dan bersamasama berpengaruh pada status kesehatan individu melalui derajat perasaan sehat fisik dan psikis, penghargaan diri, pengetahuan, dan sikap tentang sehatsakit. Secara langsung, hal tersebut berpengaruh kepada kualitas kehidupan kerja seorang perawat yang meliputi pendapatan, kesempatan pengembangan diri, keamanan, keadilan, kebanggaan, dan keyakinan dalam pilihan kerja. 4,6,8 Dengan demikian, status kesehatan secara langsung diharapkan akan berpengaruh pada kinerja seseorang. ${ }^{7}$

Dalam konseptual framework, sejarah kehidupan keluarga merupakan variabel eksogen atau independen yang mempengaruhi status kesehatan sedangkan lingkungan kerja merupakan variabel endogen atau intermediate yang berpengaruh pada perilaku gaya kehidupan dan variabel kinerja.4,6,7,10 Selain variabel utama tersebut, masih banyak variabel yang dapat mempengaruhi variabel kinerja perawat seperti motivasi kerja atau abilitas. ${ }^{11}$

Untuk menginvestigasi masalah dan variabel-variabel yang mempengaruhi kinerja perawat pada Rumah Sakit Umum (RSU) Tangerang, pendekatan ilmiah dilakukan berdasarkan konsep atau teori dan penerapannya diukur melalui model konsep tersebut. ${ }^{4,6}$ Penerapan ilmiah dipakai untuk mencari keterkaitan antarvariabel sehingga kinerja perawat di RSU Tangerang dapat diukur dan diprediksi. Hasil ini berguna bagi manajemen untuk mengukur kinerja berbasis prediksi dan merencanakan strategi terbaik meningkatkan atau mempertahankan kinerja prima melalui perbaikan atau peningkatan terhadap variabel prediktor kinerja yang diusulkan. Hal ini sangat dibutuhkan untuk mengembangkan kebijakan atau aturan tentang keperawatan berbasis kinerja sehingga dapat terjamin kepuasan dan kualitas kehidupan kerja serta terciptanya kinerja perawat yang prima di RSU Tangerang. Sebagai hasil akhir, perawat yang merupakan garda terdepan dalam pelayanan prima di RSU Tangerang akan merasa nyaman dalam bekerja serta terlindungi dari risiko dan bahaya pekerjaan keperawatan. 8,12

Saat ini, penilaian kinerja perawat di RSU Tangerang menghasilkan kinerja yang medioker dan akan sulit untuk pencapaian visi dan misi RSU Tangerang. ${ }^{13}$ Kondisi kinerja yang belum diharapkan ini disebabkan oleh peranan faktor variabel prediktor kinerja, meliputi variabel kesehatan dan kualitas kehidupan kerja yang rendah. Hal tersebut yang akan diungkap oleh penelitian ini merupakan upaya untuk membuktikan bahwa confirmatory theorythical model dapat diterapkan sebagai cara berpikir untuk melakukan intervensi dalam meningkatkan kinerja perawat di RSU Tangerang. Dengan demikian, setiap intervensi yang dilakukan mempunyai landasan yang kuat dan rasional sehingga dapat disusun strategi kebijakan keperawatan yang berbasis pada kinerja berdasarkan variabel yang diteliti tersebut. Penelitian ini bertujuan untuk melihat pengaruh dan besaran variabel-variabel kesehatan meliputi sejarah kesehatan keluarga, perilaku gaya hidup, lingkungan kehidupan, status kesehatan, dan kualitas kehidupan kerja perawat terhadap kinerja perawat.

\section{Metode}

Penelitian dilaksanakan di RSU Tangerang pada periode bulan Februari hingga Agustus 2011 dan menggunakan desain studi potong lintang. Populasi penelitian adalah seluruh perawat yang bertugas di unit rawat jalan, rawat inap, instalasi gawat darurat (IGD), intensive care unit (ICU), kamar bedah, hemodialisa, kamar operasi, dan ambulance di RSU Tangerang. Besar sampel adalah 250 dari 367 perawat yang ada, dengan kriteria inklusi adalah perawat yang telah bertugas di rumah sakit ini minimal 1 tahun sedangkan kriteria eksklusi adalah perawat yang sedang cuti dan menolak ikut dalam penelitian. Pemilihan sampel dilakukan dengan cara multistage random sampling. Instrumen yang digunakan adalah kuesioner yang 
mengukur variabel kinerja, kualitas kehidupan kerja, status kesehatan, perilaku gaya kehidupan, lingkungan kehidupan, dan sejarah kesehatan keluarga perawat. Variabel kinerja perawat diukur oleh 3 orang raters yang terdiri dari kepala ruangan (supervisor), kepala tim, dan kolega perawat tersebut. Setiap orang rater menilai maksimal 5 orang perawat. Lima variabel yang lain diukur melalui persepsi subjek. Kuesioner menggunakan sistem scoring berdasarkan pengukuran skala semantik diferensial dengan skala nilai 1-5. Nilai 1 merupakan nilai terendah dan nilai 5 merupakan nilai tertinggi suatu penilaian atau persepsi pada suatu pertanyaan. Untuk skala likert, penilaian 1-2 untuk nilai negatif, 3 untuk nilai netral, dan 4-5 untuk nilai positif. Jumlah pertanyaan pada setiap variabel bervariasi antara 14-38 pertanyaan.

Variabel kinerja meliputi indikator berdasarkan sasaran yang ditetapkan, mengikuti prosedur, inisiatif bekerja, mengerjakan tugas pokok, kemampuan bekerja sama, dan melaksanakan standar asuhan keperawatan rumah sakit. Variabel kualitas kehidupan kerja terdiri dari indikator pendapatan dan kesejahteraan, kesempatan untuk mengembangkan diri, keamanan kerja, kebanggaan pada pekerjaan, keterbukaan dan keadilan serta kepercayaan dan keramahan. Variabel status kesehatan terdiri dari indikator derajat kesehatan fisik dan psikis, derajat penghargaan diri, pengetahuan tentang sehat-sakit, dan sikap terhadap situasi sehat. Variabel perilaku meliputi indikator berolahraga untuk kesehatan fisik, kebiasaan pola konsumsi makanan dan minuman, aktivitas sosial serta kebiasaan dan kebersihan individu dalam lingkungan. Variabel lingkungan terdiri dari indikator peraturan kerja, keadaan tata ruang kerja, keadaan suhu/temperatur ruangan, suara dan cahaya di tempat bekerja serta keadaan tata ruang tempat tinggal. Terakhir, variabel sejarah kesehatan keluarga terdiri dari indikator keadaan psikologis sosial masa kecil, keadaan pola hidup waktu kecil, serta pertumbuhan dan perkembangan diri. Untuk setiap indikator pada setiap variabel diukur dengan 4-9 butir pertanyaan. Uji validitas butir pertanyaan untuk semua pertanyaan pada variabel dan reliabilitas instrumen dilakukan bersamaan dengan pengambilan data lapangan. Nilai validitas butir pertanyaan setiap variabel dengan nilai < 0,145 tidak disertakan dalam proses perhitungan selanjutnya.

Variasi jawaban semua pertanyaan pada instrumen diujikan terhadap 9 karakteristik responden untuk melihat variasi jawaban responden yang dilakukan menggunakan $\mathrm{x}^{2}$ dengan program statistik. Apabila nilai $\mathrm{p}$ uji $\mathrm{x}^{2}>0,05$, pernyataan pada instrumen tidak dipengaruhi oleh variasi karakteristik responden. Selanjutnya, data dianalisis menggunakan pendekatan
Structural Equation Model (SEM) dengan software Smart-PLS (Partial Least Square). ${ }^{14}$ Smart-PLS menghasilkan pengukuran measurement model (outer model) lengkap dengan nilai Confirmatory Factor Analysis (CFA) dan Goodness Of Fit (GOF). Nilai CFA diukur dengan melihat hasil olahan Smart-PLS pada nilai lamda (loading factor). Pada pengujian outer loading, nilai lamda harus lebih besar dari 0,5 untuk menyatakan bahwa indikator tersebut merupakan refleksi dari variabelnya. Bila nilai lamda kurang dari 0,5 dilakukan uji ulang setelah memodifikasi indikator pada variabel tersebut.

Nilai loading factor dilengkapi dengan penilaian pada analysis discriminant validity dengan cara menilai indikator reflektif variabel dengan melihat nilai cross loading antara nilai indikator pada variabel miliknya dan variabel bukan miliknya atau cukup membaca nilai Average Variance Extractor (AVE). Nilai AVE tersebut harus berada sama atau lebih besar dari 0,5. Selanjutnya, apabila nilai pada semua measurement model sudah fit, penilaian dilakukan untuk mengukur besar reliabilitas setiap lamda dengan melihat nilai composit reliability. Indikator dengan nilai yang kurang dari 0,7 dianjurkan untuk tidak dimasukkan ke dalam model, khususnya pada model eksploratori. Composit reliability perlu diperkuat dengan nilai alpha Cronbach setiap variabel untuk mengetahui tingkat keeratan atau kekuatan refleksi indikator terhadap variabel. Hubungan yang kuat harus mempunyai nilai $>0,6$ dan semuanya dilihat pada hasil perhitungan PLS.

Untuk menghitung nilai structural model, besar nilai hubungan antarvariabel yang dibangun oleh model dengan nilai GOF yang cukup dapat dilihat pada perhitungan BT atau bootstrepping dengan melihat nilai original sample yang merupakan nilai path dan nilai significancy yaitu nilai $\mathrm{T}$ statistik. Nilai path tersebut signifikan apabila nilai $\mathrm{T}$ lebih besar dari 1,28 yaitu nilai T dengan tingkat kesalahan 10\%. Langkah selanjutnya, membangun persamaan untuk model dan menghitung nilai $\mathrm{Q}^{2}$ atau $\mathrm{GOF}$ dari model yang dibangun, yang berarti menilai besaran keragaman atau variasi data penelitian terhadap fenomena yang dikaji dengan menghitung $\mathrm{R}^{2}$ pada setiap variabel model terlebih dahulu.

\section{Hasil}

Instrumen penelitian mempunyai reliabilitas $=0,9046$ $(0,842-0,975)$. Karakteristik semua variabel endogen (independen atau dependen) dan eksogen (independen) yang diteliti mempunyai distribusi data yang normal dan homogen (Lihat Tabel 1).

Ujian antara sebaran karakteristik responden dengan jawaban yang diberikan responden secara bivariat dengan uji $\mathrm{x}^{2}$ bertujuan melihat variasi jawaban 
Tabel 1. Karakteristik Responden

\begin{tabular}{llll}
\hline Variabel & Kategori & n & $\%$ \\
\hline Sebaran umur & $20-45$ tahun & 230 & 92,0 \\
& Diatas 45-50 tahun & 13 & 5,2 \\
Jenis kelamin & Diatas 50 tahun & 7 & 2,8 \\
& Laki-laki & 39 & 15,6 \\
Jenjang pendidikan & Perempuan & 211 & 84,4 \\
& D-III keperawatan & 239 & 95,6 \\
Status pernikahan & S-1/D-IV keperawatan keatas & 11 & 4,4 \\
& Menikah & 228 & 91,2 \\
Sebaran tanggungan termasuk anak & Belum menikah & 19 & 7,6 \\
& Janda/duda & 3 & 1,2 \\
& Tidak punya & 48 & 19,2 \\
& Satu tanggungan termasuk anak & 61 & 24,4 \\
Ikut pelatihan tambahan & Dua tanggungan termasuk anak & 94 & 37,6 \\
Status kepegawaian & Lebih dari dua tanggungan termasuk anak & 47 & 18,8 \\
\multirow{3}{*}{ Sebaran lama kerja } & Belum pernah ikut pelatihan & 187 & 74,8 \\
& Pernah ikut pelatihan & 63 & 25,2 \\
& PNS & 87 & 34,8 \\
Lama perjalanan ke kantor & Kontrak & 163 & 65,2 \\
& 1-3 tahun & 36 & 14,4 \\
& $>3-5$ tahun & 20 & 8,0 \\
\hline & $>5$ tahun & 194 & 77,6 \\
& sebentar (<45 menit) & 105 & 42,0 \\
& lama (> 45 menit) & 145 & 58,0 \\
\hline
\end{tabular}

Tabel 2. Nilai GOF pada Outer (Measurement) Model

\begin{tabular}{llccc}
\hline Variabel & AVE & Composite Reliability & Cronbachs Alpha & R Square \\
\hline Kinerja perawat & 0,732 & 0,942 & 0,927 & 0,018 \\
Kualitas kehidupan kerja & 0,5372 & 0,873 & 0,825 & 0,652 \\
Status kesehatan & 0,677 & 0,893 & 0,840 & 0,636 \\
Lingkungan kehidupan & 0,634 & 0,873 & 0,806 & 0,255 \\
Perilaku gaya kehidupan & 0,610 & 0,862 & 0,792 & 0,286 \\
Sejarah kesehatan keluarga & 0,741 & 0,895 & 0,825 & 0 \\
\hline
\end{tabular}

responden akibat variasi karakteristik responden tersebut. Hasil uji $\mathrm{x}^{2}$ untuk semua karakteristik dengan jawaban untuk semua variabel tidak ditemukan variasi jawaban akibat variasi karakteristik. Semua hasil uji $x^{2}$ pada setiap variabel mempunyai nilai $\mathrm{p}>0,05(0,090$ 0,655).

Pengujian outer model pada tiap variabel dengan indikatornya menghasilkan CFA dengan nilai alfa yang terletak antara 0,595-0,899 dengan nilai $\mathrm{T}$ antara 7,368,9 . Sementara, hasil pengukuran GOF measurement model dapat dilihat pada Tabel 2.

Tabel 2menunjukkan nilai GOF outer (measurement) model mempunyai nilai lamda lebih besar 0,5 untuk semua indikator pada masing-masing variabel $(0,54-0,94)$ dengan nilai $\mathrm{T}$ yang signifikan (lebih besar dari 1,28). Nilai validitas dan realibilitas juga tinggi (lebih besar dari yang dipersyaratkan) sehingga proses pembacaan dapat dilanjutkan untuk GOF inner model (Lihat Gambar 1).
Gambar 1 menunjukkan bahwa semua hubungan antarvariabel pada model mempunyai hubungan yang signifikan pada nilai $T>1,28$. Hal ini berarti pengaruh peningkatan atau penurunan yang diberikan oleh variabel prediktor atau independen terhadap variabel dependen sebesar 1 poin akan meningkatkan atau menurunkan sebesar nilai rho yang tercipta pada perhitungan model tersebut dengan tingkat akurasi minimal 90\%. Perbandingan terbalik hanya terjadi antara variabel kualitas kehidupan kerja dengan kinerja perawat karena nilai rho negatif. Selanjutnya, perhitungan GOF inner model atau model struktural pada variabel prediktor atau dependen yang langsung memberikan pengaruh pada variabel kinerja dan perhitungan persentase pengaruh antarvariabel terhadap variabel kinerja dapat dilihat pada Tabel 3 dan 4.

Variabel prediksi yang berasal dari variabel kesehatan meliputi sejarah kesehatan keluarga, lingkungan kerja, perilaku gaya hidup, status kesehatan, dan kualitas 


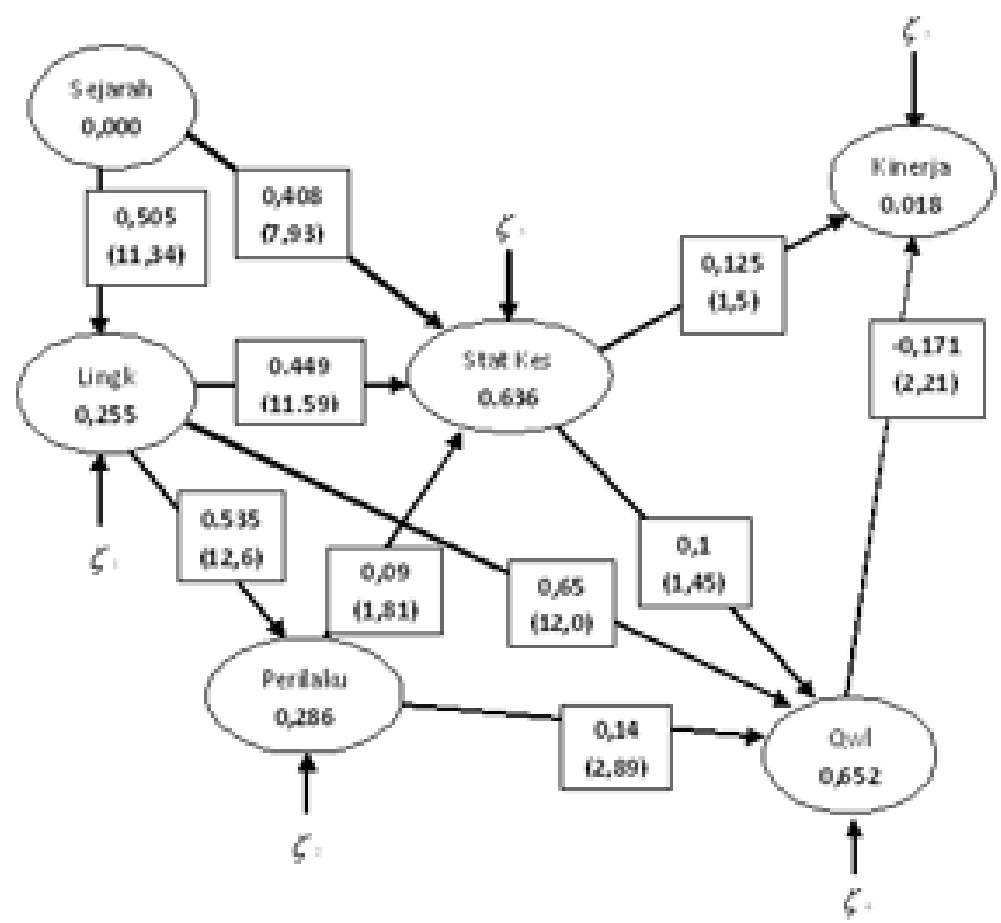

Gambar 1. Structural Model

Tabel 3. Nilai Path/Rho Langsung ke Variabel Kinerja dengan T Statistik dan Status Signifikansi pada Hubungan Antarvariabel pada Inner Model (Structural Model)

\begin{tabular}{lcccc}
\hline Hubungan Antarvariabel & Original Sample & Nilai T & $\mathbf{H}_{\mathbf{0}}$ & Tingkat Signifikansi \\
\hline Qwl -> kinerja & $-0,171$ & 2,206 & Gagal ditolak & Signifikan \\
StKes -> kinerja & 0,125 & 1,471 & Gagal ditolak & Signifikan
\end{tabular}

kehidupan kerja berpengaruh $6,16 \%$ pada variabel kinerja perawat dan $93,84 \%$ dipengaruhi oleh variabel lain. Kekuatan variabel eksogen dan/atau variabel endogen yang bersifat independen berkontribusi membangun variabel endogen yang bersifat dependen pada model teoritis ini dengan cara melihat besar nilai $\mathrm{R}$ Square pada setiap variabel endogen tersebut digambarkan pada Tabel 2.

Besar galat variabel kinerja perawat $\left(\mathrm{R}_{1}^{2}\right)$ adalah 0,982 atau dengan kata lain $98,2 \%$ kinerja perawat dipengaruhi oleh faktor-faktor selain status kesehatan dan kualitas kerja kehidupan. Dengan mengetahui besar nilai variabel lain yang mempengaruhi variabel kinerja perawat, selain variabel-variabel yang ada pada model dapat dibuat persamaan matematik pada model (Lihat Rumus 1). Model persamaan matematik menjelaskan pengaruh langsung variabel-variabel prediktif status kesehatan dan kualitas kerja kehidupan terhadap variabel kinerja perawat adalah 1,8\% dengan 98,2\% dipengaruhi oleh variabel diluar model, termasuk pengaruh tidak langsung variabel prediktor terhadap kinerja 4,36\% (6,16\%-1,8\%). Selanjutnya, perlu dihitung nilai Q-square yang berfungsi untuk menilai besaran keragaman atau variasi data penelitian terhadap fenomena yang sedang dikaji dan hasilnya sebagai berikut:

Nilai $\mathrm{Q}$-square (Q-square predictive relevance):

$$
\begin{aligned}
\mathrm{Q}^{2} & \left.\left.=1-\left(1-\mathrm{R}_{1}{ }^{2}\right)\left(1-\mathrm{R}_{2}{ }^{2}\right)\left(1-\mathrm{R}_{3}{ }^{2}\right)\left(1-\mathrm{R}_{4}{ }^{2}\right)\right)\left(1-\mathrm{R}_{5}{ }^{2}\right)\right)\left(1-\mathrm{R}_{6}{ }^{2}\right) \\
& =1-\{(1-0,018) *(1-0,652) *(1-0,636) *(1-0,255) *(1-0,286) *(1-0)\} \\
& =0,934 \text { atau } 93,4 \%
\end{aligned}
$$

Galat Model $=100 \%-93,4 \%=6,60 \%$

Keragaman data penelitian dapat dijelaskan oleh model tersebut sebesar 93,40\% atau model hasil analisis dapat menjelaskan $93,40 \%$ keragaman data mampu memprediksi atau mengkaji fenomena yang dipakai pada penelitian. Sisa yang 6,60\% dijelaskan oleh komponen lain yang mungkin belum dibangun atau tidak ada pada model ini. 
Tabel 4. Perhitungan Persentase Pengaruh Antarvariabel terhadap Variabel Kinerja pada Model Teoritis

\begin{tabular}{|c|c|c|c|c|c|c|c|}
\hline Sumber & Via & Direct Rho & Indirect Rho & Total & Direct $\%$ & Indirect $\%$ & Total $\%$ \\
\hline Qwl & Kinerja & $-0,17129$ & 0 & $-0,17129$ & 0,03 & 0,00 & 2,93 \\
\hline \multirow[t]{2}{*}{ Stkes } & Kinerja & 0,124977 & 0 & 0,108053 & 0,02 & 0,00 & 1,59 \\
\hline & Qwl & 0,098804 & $-0,0169241$ & & & & \\
\hline \multirow[t]{2}{*}{ Perilaku } & Kinerja & 0 & 0 & $-0,01408$ & 0,00 & 0,00 & 0,06 \\
\hline & Qwl & 0,137683 & $-0,0235837$ & & & & \\
\hline \multirow{3}{*}{ Lingkungan } & Qwl & 0,650466 & $-0,1114183$ & & & & \\
\hline & Stkes & 0,449085 & 0,0485249 & & & & \\
\hline & Perilaku & 0,534582 & $-0,0075285$ & & & & \\
\hline \multirow[t]{2}{*}{ Sejarah } & Kinerja & 0 & 0 & 0,008524 & 0,00 & 0,00 & 0,32 \\
\hline & Stkes & 0,407813 & 0,0440654 & & & & \\
\hline
\end{tabular}

Total

6,16

Pengaruh variabel lain diluar model yang dapat mempengaruhi variabel kinerja mempunyai nilai persentase sebesar 93,84\%

$$
\eta s=\gamma / 33 \xi_{3}+\gamma / 54 \xi_{4}+\zeta s \text { atau } \eta s=0,125 \xi_{3}-0,171 \xi_{4}+0,982
$$

Rumus 1. Model Persamaan Matematik

\section{Pembahasan}

Penelitian ini membuktikan bahwa model teoritis yang ditawarkan secara statistik bekerja pada populasi. Diskusi difokuskan kepada hasil yang didapat berupa pemberian arti pada angka statistik yang muncul sehingga memberikan makna pada pengambilan keputusan di RSU Tangerang dan dipakai untuk bahan pelajaran untuk rumah sakit umum sekelas.

Pengaruh terbesar pada kinerja perawat di RSU Tangerang akan terjadi apabila semua variabel diintervensi secara bersama-sama. Apabila dilakukan secara sendiri, variabel kualitas kehidupan kerja memberikan kontribusi pengaruh terbesar pada kinerja perawat yang diikuti oleh variabel-variabel kesehatan yang lain. Kualitas kehidupan kerja perawat sebagai komponen terbesar harus diperhatikan oleh semua pihak dalam menghasilkan kinerja perawat yang tinggi. Pada model penelitian ini, perhatian secara khusus ditujukan kepada indikator kualitas kehidupan kerja yaitu indikator yang berhubungan dengan pemberian kepercayaan, keamanan, dan keterbukaan yang harus diberikan oleh manajemen rumah sakit sehingga dengan upaya ini dapat terjadi peningkatan derajat kualitas kehidupan kerja perawat dalam jangka panjang.

Keunikan pada penelitian model ini adalah kualitas kehidupan kerja dan kinerja perawat berbanding terbalik. Hal ini menunjukkan bahwa derajat kualitas kehidupan kerja perawat yang semakin tinggi akan menurunkan tingkat kinerja perawat. Hal ini dapat dijelaskan bahwa bila perawat di RSU Tangerang telah mencapai tingkat kepuasan kehidupan kerja maka manajemen jangan terlalu berharap dapat meningkatkan kinerja mereka. Kinerja yang tinggi sulit dicapai oleh tingkat derajat kepuasan kerja perawat yang memuaskan pada model teoritis yang disusun sehingga diperlukan studi lain yang dapat menerangkan kejadian tersebut. Keadaan ini akan menyulitkan manajemen RSU Tangerang untuk menentukan program peningkatan kinerja melalui peningkatan derajat kualitas kehidupan kerja perawat.

Selanjutnya, upaya menjaga tingkat derajat kualitas kehidupan kerja yang tinggi memerlukan status kesehatan yang memadai. ${ }^{6}$ Cara yang elegan untuk mendapatkan hasil yang memadai dan positif adalah memberikan perhatian pada peningkatan status kesehatan perawat seperti melaksanakan pemeriksaan kesehatan berkala dan latihan rutin berupa senam reguler secara bersama sehingga berimplikasi terhadap peningkatan kinerja dan derajat kualitas kehidupan kerja perawat. Upaya lain untuk meningkatkan derajat kualitas kehidupan kerja perawat adalah pemberian kepercayaan (trust), rasa aman, keterbukaan (transparency), dan kesempatan yang seluas-luasnya untuk membangun derajat kualitas kehidupan kerja perawat.

Menjaga dan meningkatkan status kesehatan perawat dilakukan dengan cara memperbaiki lingkungan kehidupan dan melakukan proses kehatian-hatian dalam 
menyeleksi perawat terkait dengan sejarah kesehatan keluarga. Upaya sungguh-sungguh dengan memperhatikan perilaku gaya kehidupan perawat dalam kehidupan kesehatan adalah strategi yang harus diterapkan oleh manajemen RSU Tangerang agar dapat dihasilkan kinerja perawat yang tinggi. Peran perilaku gaya kehidupan yang dipengaruhi oleh lingkungan kerja dan berkontribusi kepada derajat kualitas kehidupan kerja serta status kesehatan memberikan hasil kurang dari 10\%. Akan tetapi, pihak manajemen RSU Tangerang sangat penting untuk memperhatikan keadaan perilaku gaya kehidupan perawat terutama menjaga status kesehatan agar kematangan para perawat dalam bekerja dapat mengembangkan sikap yang profesional dalam bidang keperawatan dan dapat dimanfaatkan untuk meningkatkan kinerja. ${ }^{15}$

Keadaan lingkungan kerja yang kondusif terutama ketersediaan tempat kerja atau suasana kerja yang menyenangkan, seperti aturan kepegawaian yang jelas dan melindungi perawat, dapat meningkatkan status kesehatan yang pada akhirnya dapat meningkatkan kinerja. ${ }^{5,15}$ Kontribusi lingkungan kerja yang cukup besar perlu mendapat perhatian khusus bagi manajemen RSU Tangerang sehingga dengan menciptakan suatu suasana kerja yang kondusif perlu menjadi salah satu prioritas kerja manajemen RSU Tangerang. ${ }^{16}$ Lebih jauh terbukti bahwa variabel sejarah kesehatan keluarga perawat merupakan landasan untuk menjaga lingkungan kerja di RSU Tangerang dan akan menghasilkan status kesehatan yang baik, dengan bukti secara statistik pengaruh langsung sejarah kesehatan keluarga perawat terhadap status kesehatan perawat adalah $40 \% .^{5}$ Besarnya pengaruh sejarah kesehatan keluarga dapat menjadi acuan bagi manajemen RSU Tangerang untuk selalu menjaga kesehatan perawat atau melakukan tindakan preventif terhadap kesehatan perawat. ${ }^{17}$

Persamaan model matematik untuk kinerja menunjukkan bahwa manajemen RSU Tangerang tidak dapat berharap banyak untuk meningkatkan kinerja perawat melalui variabel status kesehatan dan derajat kualitas kehidupan kerja perawat. Asumsi ini didasarkan pada besarnya pengaruh variabel lain yang besarnya 98\% dibandingkan dengan variabel kesehatan dan kualitas kehidupan kerja dengan tingkat keyakinan pada model confirmatory sebesar $89,59 \%$ yang nilainya diambil dari hasil perhitungan nilai predictive relevance. Walau demikian, variabel yang tergabung pada kesehatan dan kepuasan kehidupan kerja perlu dan selalu harus menjadi perhatian manajemen RSU Tangerang. ${ }^{15}$

Temuan pada awal penelitian di RSU Tangerang diketahui bahwa tingkat kinerja perawat mencapai hasil kerja yang biasa. ${ }^{13}$ Dengan temuan ini dan mengetahui konstelasi serta besaran nilai pengaruh antarvariabel yang diteliti maka untuk memperbaiki atau meningkatkan variabel kinerja perawat dapat disusun perencanaan dengan fokus. Sementara itu, upaya untuk memberi perbaikan pada variabel kesehatan perawat menjadi pilihan manajemen sebagai salah satu upaya meningkatkan kinerja perawat di RSU Tangerang. Hasil penelitian juga mengungkapkan bahwa semua variabel yang ditawarkan pada model ini dapat digunakan untuk memperbaiki kinerja perawat. Adanya upaya yang sungguhsungguh dari manajemen untuk meningkatkan kinerja perawat sebagai modal untuk meningkatkan citra rumah sakit perlu dilengkapi dengan aturan atau kebijakan keperawatan yang berbasis kinerja sehingga penelitian tentang variabel yang mempunyai kontribusi atau pengaruh perlu diperbanyak. Akhirnya, dengan adanya peningkatan kinerja perawat di RSU Tangerang dan jaminan aturan yang melindungi perawat dalam jangka panjang akan memberikan kontribusi secara tidak langsung berupa penurunan angka kesakitan untuk tingkat kabupaten Tangerang.

\section{Kesimpulan}

Penelitian ini menyimpulkan bahwa confirmatory theoretical model dapat dipakai sebagai suatu cara ilmiah dalam memilih variabel yang dapat memberikan nilai tambah terbesar pada suatu tindakan intervensi pada suatu kegiatan manajemen. Hal ini sesuai dengan hasil yang didapat pada penelitian yaitu variabel kinerja perawat yang dipengaruhi oleh variabel prediktor, variabel kesehatan dan variabel kualitas kehidupan, terbukti memiliki pengaruh yang tidak cukup besar terhadap kinerja perawat sehingga intervensi tidak cukup untuk meningkatkan kinerja perawat secara maksimal. Dengan demikian, manajemen rumah sakit dalam meningkatkan kinerja perawat memerlukan intervensi terhadap variabel-variabel lain diluar variabel yang ada dalam penelitian ini.

\section{Saran}

RSU Tangerang dan RSU sekelasnya perlu dipertimbangkan variabel-variabel lain seperti variabel manajemen meliputi variabel ability, variabel kepemimpinan, dan variabel motivasi untuk meningkatkan kinerja perawat disamping variabel prediktor yang ada pada penelitian ini dapat dipakai untuk subjek yang harus diintervensi. Oleh karena itu, atas dasar perlunya intervensi kepada variabel lain maka penelitian lanjutan terhadap confirmatory theoretical model perlu diperluas.

\section{Daftar Pustaka}

1. Cherry B, Jacob SR. Contemporary nursing: issues, trends, and management. 3rd ed. Elsevier M; 2005. [cited 2009 April 12]. Available from: http://evolve.elsevier.com. 
2. Clark RE. The economic benefits of supported employment for persons with mental illness. J. Mental Health Policy Econ. 2008; 187: 63-7.

3. Cole MA, Neumayer MA. The impact of poor health on total factor productivity. Journal of Development Studies. 2006 August [cited 2009 April 20]; 42 (6): [about 12 p]. Available from: http://imformaworld.com.

4. Budiharto. Pengantar ilmu perilaku kesehatan dan pendidikan kesehatan gigi. Jakarta: EGC; 2010.

5. Ulrich BT. Healthy work environments. Critical Care Nurses' Work Environments 2008: A Follow-up Report. Critical Care Nurse. 2009 April [cited 2009 August 14]; 29 (2). Available from: http://www.ccnonline.org.

6. Green L. Precede-proceed model of health program planning and evaluation: new features and updated citations in new 4th edition of health program planning "an educational and ecological approach”. 2005 [cited 2010 July 27]. Available from: http://www.lgreen.net.

7. Robbins SP. Organizational behavior: human behavior at work. New Jersey: Prentice Hall Pearson Education Inc; 2003.

8. Barnum BS, Karlene M, Kerfoot KM. The nurse as executive. 7th ed. Gaithersburg: Aspen Publishers; 2005.

9. Kivimäki MP, Voutilainen P, Koskinen P. Job enrichment, work motivation, and job satisfaction in hospital wards: testing the job characteris- tics model. J Nursing Management, 2008; 310: 87-91.

10. Community Health Improvement Partner. Community health: a different perspective of conceptual model of the community. 2001 [cited 2010 July 28]. Available from: http://sandiegohealth.org.

11. Robert LM, John HJ. Human resources management. Salemba Empat: Jakarta; 2006.

12. Nasri SM. Modul kuliah K3 dasar program strata dua (s2) magister kesehatan masyarakat kelas e-learning. Depok: Fakultas Kesehatan Masyarakat Universitas Indonesia; 2009.

13. Rumah Sakit Umum Tangerang. Profil rumah sakit umum Tangerang tahun 2010. Tangerang: Rumah Sakit Umum Tangerang; 2010.

14. Ghozali I. Structural equation modelling: metode alternatif dengan partial least square (pls). 2nd ed. Badan Penerbit Universitas Diponegoro: Semarang; 2008.

15. Hafizurrachman. Health status, ability, and motivation influenced district hospital nurse performance. Medical Journal of Indonesia. 2009; 18 (4): 283-9.

16. Gifford DB, Zammuto RF, Goodman EA, Hill KS. The relationship between hospital unit culture and nurses' quality of work life. J Healthcare Management. 2007; 247: 281-4.

17. Health Indicators 82-221-XIE. Health status. Health Indicators. 2001 [cited 2009 August 12]; 3. Available from: http://www.statcan.gc.ca/pb. 